\title{
Analysis of Public Service Advertisement's Creation of Fashion Brand Image
}

\author{
Xueying Kuang, Shui Jin* \\ Beijing Institute of fashion Technology, Beijing, China 10012
}

\begin{abstract}
The problem solved by this article is that the new media is increasingly showing a vigorous development, the market competition is becoming more and more fierce, media technology and media are changing rapidly, and traditional advertising can no longer meet the competitive development of some modern brands and the needs of the audience. The research process of this article is from the perspective of public service advertisements, studying the development status of domestic and foreign brand public service advertisements and the case analysis of its application in brand image shaping and dissemination. The conclusion of this article is that now that homogenization is getting higher and higher, if you want to build a brand that is recognized and loved by consumers, you must effectively distribute brand products, reflect the brand's social responsibility and love. The unique research of this article is the integration of public service advertising and fashion brands to create an innovative research model that combines practice and promotion.
\end{abstract}

Keywords: Public service advertising, Image shaping, Sense of responsibility

\section{Introduction}

Nowadays, new media is showing an overall trend of vigorous development, and market competition is becoming more and more fierce, the media technology and medium are changing with each passing day. Traditional advertising can no longer meet the competitive development of some modern brands and the needs of audiences. Therefore, the advent of new media era will also bring a new form of brand image shaping, Public service advertising. With the innovation and progress of science and technology, public service advertising has more development opportunities, but the increasingly complex new media environment also makes public service advertising face unprecedented difficult challenges. The corporate behavior and brand competition of fashion brands will be launched at a higher level. The scale operation and grouping trend of corporate brands are also more obvious. Brand competition has developed from resource competition, talent competition and information competition to The overall competition between enterprises-brand image competition [1]. A brand can devote itself to the interests of the society, think about it from the standpoint of the public, conscientiously shape the good public image of the brand in the society, and make it win the favor of the public and consumers in the market competition and be invincible.

* Corresponding author: jinshui@126.com 


\section{Public welfare and brand win-win under the media ear}

\subsection{The social value of public service advertisements}

In the report of the 19th National Congress of the Communist Party of China, General Secretary Xi Jinping pointed out that it is necessary to cultivate and practice the core values of socialism and give play to the leading role of the core values of socialism in national education, the creation of spiritual civilization, and the creation, production and dissemination of spiritual and cultural products [2]. Especially in September 2017, the Central Committee of the Communist Party of China and the State Council issued the "Opinions on Creating a Healthy Growth Environment for Entrepreneurs and Promoting Excellent Entrepreneurship to Better Play the Role of Entrepreneurs" to further promote and promote entrepreneurship [3]. At the same time, the rapid development of society is bound to bring more support to public service advertising. The state has also given updated requirements and industry basis for public service advertising. The 2016 "Interim Measures for the Promotion and Management of Public Service Advertising" won the national business Examined and approved by the Bureau of Administration of the General Administration of Administration, issued by six ministries and commissions at the same time, which pointed out that "public welfare advertisements funded by enterprises for design, production, publication or naming can be marked with the name of the enterprise and the trademark logo". These national policies and corporate behaviors are not only related to social economic development, but the ultimate goal is to build a more harmonious society. Therefore, it can be said that there is a complementary relationship between public service advertising and social development.

\subsection{Image enhancement of fashion brands}

In recent years, in the face of fierce market competition, fashion brands have fought fiercely, and many brands compete for price with quality competition, resulting in a negative growth in profit income, and ultimately undoubtedly caused a huge obstacle to the development of the brand itself. At the same time, the investment in brand promotion is obviously insufficient, and it is caught in a vicious circle. The competition of modern fashion brands is no longer just a single-level competition centered on products, but has transitioned from the competition of products to the era of brand competition. In short, it is the competition of brand image.

Consumers' memory of a brand is essentially the memory of the brand's image, and consumers' choice of products is not only considering the price factor, but also depends on the consumer's inner identity. If a brand does not have a special flash point or It is a clear positioning, and it is easy to be forgotten by consumers. Brands without a personal image are not easy to exist for a long time. Under the market economy, brands are essentially products of market competition, a sign of quality, and a sign of consumer recognition. Today's market competition is actually the competition between brands [4]. Improving the brand image and sustainable competitiveness is not a one-off, one-shot thing, which is essentially a huge project that requires full consideration.

\subsection{Mutual benefit and mutual benefit of public welfare and brand}

With the advancement of technology, new media is showing a vigorous development trend, the competition between brands is intensifying, pure commercial advertising may bring temporary profits to corporate brands, but if you want to continue healthy development, keep 
the brand lasting. The vitality of commercial advertising alone will not work [5]. Traditional advertising can no longer meet the needs of the development of the modern advertising industry and the audience. It is precisely in this context that the advent of the new media era has brought a new form of advertising, Public service advertising, thus the vigorous development of the advertising industry provides a more effective communication carrier. In the invisible battlefield of fashion brand competition, its brand behavior and brand competition will be launched at a higher level, and the scale operation and grouping trend of brand companies are more obvious. Brand competition has been from resource competition, talent competition, information Competition has developed into a brand's overall competition-image competition [1]. If a brand can serve the public interest, and thus shape its own social public welfare image, gain the goodwill and recognition of the public, and resonate with the society, then it can win the good impression of public and consumers, and be invincible in the market competition.

Western countries have a long history of development in the advertising industry, and the creation system of public service advertisements is more mature and diverse. The investment and research promotion of foreign fashion brands in public service advertisements has entered a mature period. These large companies are keenly aware that although public service advertisements cannot directly promote their products, on the contrary, this mode of dissemination of weakened business information will also directly serve the interests of the public, so as to achieve better communication with consumers. Public service advertisements can greatly highlight and emphasize the brand's social responsibility, and give the company a good and noble social public image. Frequent broadcasting can also strengthen the brand impression that the brand brings to the public [5]. Indirectly brings to the brand Good reputation and many other intangible value returns. Being able to build a noble and good image of the brand in the minds of consumers is actually a way to promote the brand itself. It can be seen that the impact of public service advertisements on brands and companies seems to have no immediate improvement effect, but its long-term impact in consumers' minds and consumers' recognition of their overall brand image is any conventional model of commercial advertising could not be compared with and surpassed.

\section{Public service advertisements shape the brand's own image}

\subsection{Embodiment of brand responsibility}

In fact, the sustainable and healthy development of modern brands depends on whether they can obtain public recognition and support, and whether they have a brand image that is deeply rooted in people's hearts, and whether they can have far-reaching influence. Brands make public service advertisements to disseminate and explain various issues that arise in the development of social civilization, guide the public to pay attention to certain social issues, and change public attitudes and views on these public welfare issues [6], and urge the public to make The good things that are beneficial to society and the natural environment, supporting the advocacy of a certain social style to promote the alleviation or resolution of social problems, played a role in social education. A questionnaire survey I conducted also shows that all sectors of the community generally have a certain preference for public service advertising brands, and do not exclude public service advertising. Secondly, as the pressure of competition among brands has increased, while commercial advertising has sprung up like mushrooms, there are also some urgent problems to be solved. For example, some commercial advertisements are obviously false and deceptive, which obviously exaggerates the role and quality of their finished products. The utilitarian nature and indirect profitability of public service advertisements are in sharp contrast with commercial advertisements. Not 
only can they establish a good and noble social image of the brand, highlight the brand's strong sense of social responsibility and love, but also allow consumers' emotional experience and psychological satisfaction In the first place, it unconsciously strengthened the confidence in the brand, and established a good image in the public's mind in a subtle way, thus enhancing the brand's popularity and brand value.

\subsection{Enhancement of brand affinity}

Emotions are indispensable in our lives, but what are emotions specifically? I think it is a deep connection, the result is to make people think deeply or resonate. In today's social life, consumers' acceptance and choice of a brand is not only to satisfy the functional value of its brand, but also to be an emotional appeal [5]. As the saying goes, people who win the hearts of the people win the world, and public service advertisements can eliminate consumers' doubts in the easiest way, and then narrow the distance with consumers. Good public service advertisements can "single hit" with the inner thoughts of consumers, starting from the scenes and examples we are familiar with, letting The audience has a strong sense of resonance and achieves the purpose of long-term communication, which is also the communication effect that ordinary commercial advertisements cannot achieve.

"Advertisement is the epitome of life, showing all kinds of human beings [7]. And there is a type of advertisement that not only expresses life, but also forms a force for good, and promotes the progress of society little by little. This is public welfare. advertising". Relative to the all-star endorsement tactics frequently used by competitor Pepsi, Coca-Cola has always been more enthusiastic about digging up the most subtle warm stories to gain popularity, and chooses to communicate deeply with consumers emotionally. Coca-Cola's public service advertisements are more of an emotional and spiritual lubricant, some even focus on sensitive and heavy social issues. For example, one of their public service advertisements focusing on South Asian workers working in Dubai has successfully captured the issue of the social working class. As we know that there are a lot of workers from South Asia. In order to save every cent of their hard-earned money, they are not even willing to spend phone calls to call home, so the connection with their loved ones is brutally cut off by reality.

After the Coca-Cola company learned about this situation, they immediately invited the relevant professional team to develop a phone booth device that can use the Coca-Cola bottle cap as a call fee, so that workers in foreign countries can Listened to the voices of distant relatives at a lower telephone rate, and used this as a content to shoot public service advertisements, which won unanimous praise from the general public and inspired thousands of consumers. Curiosity and pain points have made the brand warmer and more humanize. While shaping the image of the Coca-Cola company full of social responsibility, it has also achieved good social benefits [5]. From this we can see that public service advertising is using its unique value orientation to create a more harmonious and beautiful society for us.

\section{Public service advertisements are a powerful tool for brand communication}

\subsection{Soft ads establish closer communication}

Today, with the rapid development of society, the public is becoming more and more sensitive and antipathy to hard advertisements with too much brand commercial information, and they are more and more passively accepted. In such a large environment, consumers' psychological resistance to commercial advertising is increasing day by day, and public service advertisements stand precisely from the perspective of consumers, observing the 
feelings and feelings of thousands of people, and appearing as a bosom friend. This approach breaks people's defense against the brand psychologically, aroused wide public resonance and goodwill, and made up for the declining trust of commercial advertising, thus winning the trust of consumers. Public service advertisements be emotional in the content and appeal of the story, and stimulate the audience's "emotional response" is undoubtedly an effective strategy. This shows that public service advertisements enjoy higher acceptance than commercial advertisements, and are easier to impress and persuade the audience.

\subsection{Cumulative reputation improves audience recognition}

A responsible brand will conduct behaviors that give back to the society, and brand making public service advertisements and participating in public service actions is one of the effective ways.

While consumers stop to watch the brand's high-quality public welfare advertisements seriously, the resonance that emerges from their hearts is actually a natural acceptance of the brand. The brand can use its inner emotional explosive power to win the resonance of the audience. Once the resonance is formed, the emotional effect of the advertisement will be reached, and the brand reputation will be quietly absorbed and improved.

IKEA, a well-known international home furnishing chain brand, is closely linked to the attributes of the industry and is extremely close to consumers. In their advertisements, it advocates "a healthier planet, starting at home: exploring products and solutions for a more sustainable life. " Compared with the slogan advertising of Rotten Street, "Protect the environment, everyone is responsible, protect the environment, and start with me", this kind of communication that closely follows the value of the brand, the former pays more attention to humanized communication with consumers and is more humane, creating a warm, harmonious and comfortable atmosphere and imagination space. This advertisement also properly spreads the business philosophy of the IKEA brand, and the appeal of the advertisement and the connotation of the brand have been cleverly integrated. This act of protecting the environment from its own product actions has shaped the image of an IKEA company full of social responsibility, while also accumulating public reputation for the brand. And the way of emotional persuasion makes it easier for consumers to have a good impression on the brand, so that consumers can readily accept the choice of furniture decoration at home can also contribute to the protection of the global environment, thereby improving the audience's sense of identity and brand loyalty, and achieving good Social benefits.

After the brand gains the trust of consumers, consumers will have a tendency to "affirm analogies." In the future consumption, the brand's products or services will be implicitly considered as the first consideration, thereby increasing brand loyalty. The rapid development of the economy has also promoted the diversification of commodities, and there are countless homogenous commodities, and in the face of this situation, consumers will naturally choose those familiar and well-publicized brand commodities.

\subsection{Promote public welfare as a role model}

Fashion brands are not only be the fighters in the fierce market competition, but also the promoters of society towards harmony and beauty, assuming their due social responsibilities. The mistakes and deviations in the direction of social ethos and values may affect the moral system of the entire society, and will also hinder the harmonious and stable development of society [8].

Public service advertising is a mirror that reflects society. It is characterized by a wide range of audiences, strong penetration and strong themes. It is a reliable communication 
carrier for the social masses to spread mainstream social values, and to promote and advocate to the public through the form of advertising These positive and positive messages. On the one hand, brands can integrate real-time social hot issues or ideas that the brand wants to promote into the public service advertisement through a unique performance method, which can resonate with the public and achieve publicity and advocacy.

On the other hand, in this large environment, everyone's own behavioral norms will be subtly influenced and constrained by this positive and positive energy environment, no matter in which class or environment, Such positive ideas will be vigorously spread through public service advertisements, [8] when the masses will change in a positive direction, which can enable everyone in the society to form a good moral concept system, and then regulate themselves. The process of audience watching public service ads is actually the process of accepting their content ideas and value orientation. [8] The ancients said that "the person who is close to Zhu is red, and the person who is close to Mo is black". That means even an uneducated personality can be influenced and educated by a large number of outstanding public service advertisements, so that everyone can continue Study and progress in order to improve and improve one's own moral behavior and jointly promote social development and progress.

For example, the National Bank of Dubai ENBD (one of the largest banks in the UAE) launched a heart-warming public service advertisement on November 13 to commemorate World Good Day [9]. This public service advertisement tells the story of the indifferent selfish male character who is finally "infected" by kindness. In the advertisement, the male master actually insinuates everyone in real life who refuses to help. But in fact, as long as you are willing to try to help others once, you will feel the joy of giving. Humans are social animals that are easily affected by infection. A smile, an action, and a help are likely to embark on a new life track. On the day of International Friendship Day, ENBD used this public service advertisement to depict the power of help. Once this public service advertisement was broadcast, it caused widespread concern and deep reflection from the public. It is telling us that "you are probably the one who helped him take off his indifferent coat". While advocating mutual help, "coldness" should not be synonymous with people in contemporary society[10].

\section{Conclusion}

\subsection{Integration of brand and public welfare becomes possible}

With the continuous development and maturity of science and technology, new media and new technologies are rapidly entering all walks of life, and the advent of the Internet era and the emergence of various new media have provided various effective ways for the dissemination of public service advertisements. Public service advertisements require innovative forms of communication, augmented reality interactive technology, and the use of innovations in communication forms and the enhancement of interactive participation is the key to the effect of public advertisements in stimulating widespread communication. [11] One of the biggest features of the new media era is mass media-covering the vast majority of online media users, especially with the popularization of mobile phone short video software. Brands making public service advertisements should be more compatible with the characteristics of mobile phones, fit the communication methods of mass media, and make use of the interactivity and immediacy of mobile networks to spread widely.

Secondly, with the help of new media and new technology forms, improving the interactive participation of public service advertisements can make up for the shortcomings of the traditional one-way communication of public service advertisements. [12] For 
example, the "VR + Public Service Advertisement" model can effectively stimulate the curiosity and participation enthusiasm of the audience, provide the audience with immersive feelings, enhance interactivity and satisfy the emotional desire of the audience, so as to achieve the effect of shocking the soul and effectively resonate with the audience, Which enhances the interest, interactivity, communication power and influence of public service advertisements, making the effect of advertising delivery more significant.

The more important thing is that the shooting of public service advertisements is indispensable for the image building of fashion brands, and it is even more effective than traditional propaganda. [13] Public service advertisements have unique advantages such as wide audience groups, resonating with the public, diverse communication carriers, high arrival rate, high transmission rate, and wide communication channels. They can stimulate the inner resonance of the audience to spontaneously spread and form a good social effect. At the same time, it creates a good positive brand image in a wider range and at a deeper level, so that the brand can continue to develop healthily.

\section{Acknowledgments}

This work was supported by the Special Fund for the Construction of High-level Teacher's Group of Beijing Institute of Fashion Technology, Project No.biftxz201905.

\section{References}

1. G Chao. The development status and countermeasures of public service advertising in my country. News enthusiasts (the second half of the month), (2010).

2. C Qi. An Analysis of the Path of Socialist Core Values Leading the Construction of Campus Culture in Universities_-Taking Hengyang Teachers College as an Example. Knowledge Economy, 23, 44+46, (2018).

3. J Yin. Promoting the spirit of excellent entrepreneurs to better play the role of entrepreneurs. Economic Management: Digest Edition.

4. Q Li. Research on the Construction of Regional Tourism Brands-Taking Dahuangshan Tourism District as an Example, (2009).

5. H Qin. On public service advertising and corporate brand image building. News Window, 04, 55-56, (2014).

6. D Xu, C Wang. An Analysis of the Cultural Connotation of the Chinese Characters in the Water Department of "Commonly Used Character Tables in Modern Chinese". Journal of Liaoning Normal University (Social Science Edition), 6, (2016)

7. Chinese advertising magazine. Santa also has no place to give gifts.

8. http://www.sohu.com/a/278720379_657211,2018-11-30

9. S Lin. Analysis of the characteristics of public service advertisements and their ideological and political education functions. Xuelun, 12, 178-179+186, (2018)

10. Y Wang. Analysis of the style of campus public welfare advertisements. Young writers, 21, 95-95, (2010)

11. Advertisers_discard.2018 Top Ten Public Service Advertisements.

12. http://www.sohu.com/a/288289192_117194, (2019)

13. F Qin, Z Gu. Pathfinder's brand communicateon research, China Sports Industry and Sports Goods Industry Development Forum, 0, (2018) 
14. J Zhang, M Hu. Research on the development trend of the integration of VR technology and public welfare communication [J]. Sound Screen World·Advertiser, 04:125-128, (2019)

15. O'Barr W M. Public Service Advertising. Advertising \& Society Review, 7(2):15971597, (2006) 